HALINA PARAFIANOWICZ (Białystok)

\title{
JACQUELINE KENNEDY ONASSIS: LEGENDARNA AMERYKAŃSKA FIRST LADY W AMERYKAŃSKICH PUBLIKACJACH
}

W USA nie ustaje zainteresowanie Jacqueline Kennedy Onassis, którą przypomniano ostatnio szerokim rzeszom Amerykanów w kilku bardzo popularnych, acz kontrowersyjnych, filmach telewizyjnych. Od jej śmierci (19 maja 1994 r.) opublikowano też rozliczne artykuły i książki o niej. I nadal powstają kolejne prace ${ }^{1}$ o tej niezwykłej i w gruncie rzeczy mało znanej, bo zmitologizowanej, tajemniczej kobiecie.

Jedną $z$ najnowszych publikacji o Jacqueline Kennedy Onassis jest książka Carla Sferrazzy Anthony'ego ${ }^{2}$, który już w swoich wcześniejszych pracach o amerykańskich prezydentowych poświęcił jej sporo życzliwej uwagi. Podstawę źródłową niniejszej publikacji stanowią wywiady autora z przy jaciółmi, rodziną i osobami, które współpracowały z Jacqueline Kennedy Onassis oraz źródła archiwalne, ikonograficzne i filmowe dotyczące jej życia i aktywności publicznej, znajdujące się w Bibliotece Prezydenckiej Johna F. Kennedy'ego w Bostonie. Wykorzystane też zostały rozliczne wspomnienia, pamiętniki, autobiografie i dzienniki wielu osób, które ją bliżej znały, jak również biografie oraz publicystyka dotycząca tytułowej bohaterki. Baza źródłowa jest zatem bogata, aczkolwiek wykorzystana selektywnie. Autor zresztą zastrzegł (s. 4), że jego zadaniem nie było wyjaśnianie wszystkich szczegółów z życia Jacqueline Kennedy Onassis oraz spekulacji

1 W katalogu Biblioteki Kongresu znajduje się 61 książek o Jacqueline Kennedy Onassis, z tego znaczna część ukazała się już po jej śmierci. Przykładowo w 1994 i 1995 r. po 6 pozycji, w 1996 r. - 8, w 1997 r. - 3. W tymże katalogu znajduje się 6 zapowiedzi wydawniczych kolejnych książek o niej, a z pewnością będzie ich więcej.

2 Carl Sferrazza Anthony, As We Remember Her. Jacqueline Kennedy Onussis in the Words of Her Family and Friends, New York: Harper Collins Publishers, 1997, s. 376. 
i kontrowersji wokół jej postaci, ale raczej próba pełniejszej prezentacji jej jako osoby, kobiety usilnie starającej się zachować własną tożsamość. I to mu się udało, choć oznacza to także bardzo subiektywny wybór, a w konsekwencji i taki wizerunek swojej bohaterki.

Praca podzielona jest na 10 chronologicznie ujętych rozdziałów, poczynając od dzieciństwa Jacqueline Bouvier, a kończąc na ostatnim roku jej życia. Rozdział piąty, traktujący o latach w Białym Domu (s. 127-207) jest, ze zrozumiałych względów, znacznie bardziej rozbudowany. Sporo uwagi poświęcił też autor jej działalności publicznej, jako wdowy po prezydencie Kennedy'm, oraz pracy Jacqueline Kennedy Onassis w nowojorskich wydawnictwach. Dopełnieniem tekstu są liczne fotografie, zazwyczaj mniej znane i często dotyczące jej życia prywatnego.

Jacqueline Kennedy od początku zaakceptowana została przez rodaków w roli First Lady, choć ona sama nie bardzo wiedziała, jak ma ją pełnić i nie lubiła tego tytułu. Po inauguracji prezydentury męża stwierdziła, że dostosuje się do tradycji i, jak jej poprzedniczki, w Białym Domu będzie pełnić stosowne funkcje ceremonialne. Ale natychmiast dodała, że postara się wszak nie zaniedbać swoich wcześniejszych zainteresowań sztuką (s. 129).

I słowa dotrzymała, bowiem jej ambitnym zadaniem stała się restauracja Białego Domu, a zwłaszcza przywrócenie niektórym jego wnętrzom dawnej świetności. Nazywała to „swoim projektem", którym zajmowała się z ogromną pasją i oddaniem. Po latach z pewną dumą i satysfakcją przyznała, że nigdy w życiu nie pracowała tak usilnie nad realizacją jakiegokolwiek zamierzenia. Ale swój cel osiągnęła i przeprowadziła rekonstrukcję Białego Domu, wzbogacając go o cenne dzieła sztuki i antyki (s. 139).

Jacqueline Kennedy przygotowała też pierwszy Przewodnik po Biatym Domu, który cieszył się ogromną popularnością w USA, a zwłaszcza wśród turystów odwiedzających ten najsłynniejszy amerykański dom. 14 lutego 1962 r. w godzinnym programie telewizyjnym prezydentowa $z$ nieukrywaną dumą i radością „oprowadziła" Amerykanów po rezydencji (s. 143). Przybliżyła w ten sposób milionom rodaków Biały Dom, a zarazem zaprezentowała się im jako First Lady.

Biały Dom za czasów Kennedych tętnił życiem i stał otworem nie tylko dla licznych polityków i biznesmenów, ale także artystów, pisarzy, dziennikarzy i muzyków, co niewątpliwie było głównie zasługą Jacqueline Kennedy. Były to głośne, i do dziś wspominane nostalgicznie przez wielu, „lata Kamelotu". W Białym Domu gościli m.in.: Pablo Casals, Isaac Stern, Mieczysław Horszowski, Alexander Schneider, liczne zespoły muzyczne, także szekspi- 
rowskie trupy teatralne. Na uroczystych obiadach bywali tam również Saul Below, Arthur Miller i cała plejada współczesnych malarzy, poetów, producentów filmowych etc. Nawet Tennessee Williams, któremu „było za daleko, by wpaść tam na obiad", po telefonie Jacqueline Kennedy zdanie zmienił i gościł w Białym Domu (s. 168).

Biały Dom w czasach Kennedych wyróżniał się szczególną atmosferą, również ze względu na dzieci. Caroline i John byli obiektem dumy nie tylko rodziców, ale i przeciętnego Amerykanina, który w gazetach mógł nieraz oglądać piękne zdjęcia Kennedych $z$ komentarzem o wydarzeniach w życiu rodzinnym prezydenckiej pary i ich potomków. Kreowany oficjalny image „pierwszej amerykańskiej rodziny”, jak można się domyśleć, był dosyć odległy od stanu faktycznego, odbiegającego od ideału. Ale wtedy, na bieżąco wylansowano bardzo pozytywny wizerunek Kennedy'ego, skrzętnie ukrywając przed opinią publiczną kulisy jego życia prywatnego. W gruncie rzeczy życie rodzinne Kennedych, czym ekscytowała się cała Ameryka, zostało zmitologizowane i pozostawało po trosze zagadką. Dopiero potem opinia publiczna dowiedziała się o jego burzliwym życiu osobistym, co do dziś budzi wiele kontrowersji i towarzyszących im emocji.

Jacqueline Kennedy, także jako First Lady starała się być po prostu sobą, zachowując naturalność i spontaniczność, która w połączeniu z młodością i elegancją oraz dozą dyplomacji dawała zazwyczaj korzystny efekt. Niedługo potem uznana została przez amerykańskie mass media za czarującą gospodynię Białego Domu. Z czasem kobiety naśladowały nie tylko jej sposób bycia, stroje, ale i uczesanie, nadając jej honorowy tytuł „Lady of Fashion". Betty Ford twierdziła, że w sprawie ubiorów i mody zapanowała „swoista epidemia”, gdyż Jacqueline Kennedy „miała tak wspaniały gust, że wszystkie kobiety w Waszyngtonie i w całej Ameryce chciały ją naśladować" (s. 134).

Jackie, jak ją powszechnie nazywano, była bodaj najbardziej uwielbianą amerykańską prezydentową, o której rodzima prasa pisała $z$ wielką admiracją, zachwytem i dumą. Okrzyczano ją nie tylko „Amerykańską pięknością”, „Ekscelencją elegancji”, „Damą wdzięku i czaru”, ale również „Księżniczką”, a nawet „Królową Ameryki". W ankietach Gallupa od 1961 r. przejęła po Eleanor Roosevelt palmę pierwszeństwa jako najbardziej podziwiana kobieta w USA, a w 1962 r. została uznana za „Pierwszą Damę Świata Zachodniego".

Amerykańska First Lady cieszyła się dużą popularnością także za granicą. W trakcie wizyty we Francji w 1961 r. całkowicie podbiła serca Francuzów i osobiście prezydenta Charles'a de Gaulle'a, ujętego jej znakomitą 
znajomością języka i kultury francuskiej. Bardzo serdecznie witano ją również w Wiedniu (czerwiec 1961 r.), gdzie oczarowała z kolei Nikitę Chruszczowa prowadzącego rokowania na szczycie z Kennedym. Radziecki przywódca, który odbył z nią krótką rozmowę, wspominał potem, że była nie tylko młoda, energiczna i piękna, ale i inteligentna (s. 151). Jej wdziękowi, jak informowały amerykańskie mass media, nie oparł się także królewski Londyn.

Po zabójstwie Kennedy'ego popularność Jackie sięgnęła bodaj szczytu. Osierocona wdowa $z$ dwójką małych dzieci (a takie zdjęcia obiegły cały świat) wzbudzała żal i szacunek. I taką właśnie Jacqueline Kennedy zapamiętano - godną, dzielną i dostojną wdowę w żałobie. Stała się „narodową ikoną", „świętością amerykańską" i swoistym pomnikiem dla milionów rodaków, jak nieraz pisano w prasie. Była także świadectwem mitu Kennedy'ego. Ale nie była to rola łatwa, tym bardziej że wciąż „upubliczniano" jej życie, podczas gdy ona potrzebowała przede wszystkim spokoju, także dla swoich dzieci. Jej bliscy wiedzieli, że Jackie zawsze chciała być po prostu sobą, ale świat od niej oczekiwał, by pozostała przede wszystkim legendą. Buntowała się przeciwko temu i starała się, tak jak umiała, temu przeciwstawić.

Jacqueline była bardzo zaprzyjaźniona $z$ bratem zmarłego męża, Robertem, który też otoczył ją i dzieci serdeczną opieką. Z niepokojem obserwowała jego dalszą karierę polityczną i aspiracje do prezydentury, bowiem - jak wyznała Arthurowi Schlesingerowi - obawiała się, że i „jego spotka taki sam los, jak Jacka. W tym kraju jest tak wiele nienawiści i nawet więcej osób nienawidzi Bobby'ego, niż Jacka. (...) Mówiłam Bobby'emu o tym, ale on - o odróżnieniu ode mnie, nie jest fatalistą" (s. 235-236).

Niedługo potem kandydat demokratów na prezydenta, Robert Kennedy, zginął od kuli zamachowca w hotelu w Los Angeles. Po tym zabójstwie Jacqueline Kennedy uznała, że i jej dzieci noszące to samo nazwisko „mogą być tarczą strzelniczą". Nie czuła się bezpiecznie i nerwowo, wręcz desperacko, jak przyznawali przy jaciele, poszukiwała opieki (s. 237).

Jej ślub z Arystotelesem Onassisem (20 października 1968) zaszokował rodaków, którzy odebrali to jako policzek wymierzony Ameryce. Rodacy nie chcieli (a może nie umieli) rozstać się $z$ jej wykreowanym image i utrwaloną legendą. Amerykanie woleli ją ustawić „na piedestale”, a ona - jak wyznała przy jaciółce - „wolała $z$ niego spaść, niż na nim zamarznąć”.

Najbliżsi wiedzieli jak bardzo zależało Jackie na wyrwaniu się z tego „ślepego zaułka", choć też nie wszyscy i nie od razu zaaprobowali jej decyzję o ponownym małżeństwie. Przyrodni brat Yusha Auchincloss przyznał 
potem, że Jackie „chciała mieć własne życie" i taką szansę stwarzał związek z Onassisem (s. 240). Siostra Lee Radziwill twierdziła, że Jackie była zmęczona ciągłym zainteresowaniem mass mediów jej osobą i brakiem prywatności, którą zawsze ceniła. I dodała: „Onassis jest wystarczająco bogaty, by zapewnić jej dobre życie i wystarczająco potężny, by zabezpieczyć jej prywatność" (s. 248). Zaś sen. Edward Kennedy stwierdził potem, że Jacqueline w Onassisie „znalazła oparcie i ochronę dla swoich dzieci. Myślę, że czuła się przy nim bezpiecznie, zwłaszcza po 1968, kiedy była pełna obaw i czuła się zagrożona" (s. 242).

W marcu 1975 r. ta młoda i piękna kobieta została powtórnie wdową. Bilans niespełna 7-letniego małżeństwa z Onassisem, zresztą też dalekiego od idylli, uznała za dodatni. Stwierdziła, że „Aristoteles Onassis przyszedł mi $z$ pomocą $w$ bardzo trudnym dla mnie czasie. Znaczył dla mnie wiele. Wprowadził mnie w świat, w którym można było znaleźć zarówno szczęście, jak i miłość" (s. 243).

Niedługo potem Jacqueline Kennedy Onassis podjęła pracę w nowojorskim wydawnictwie Viking, a następnie w Doubleday, gdzie nareszcie „czuła się jak w domu". Wydawała albumy, interesujące biografie, pamiętniki z czasów II wojny światowej, prace historyczne, a także książki dla dzieci. Robiła to, co lubiła. W 1977 r., w ramach projektów wydawniczych, odwiedziła Związek Radziecki, a w dwa lata później Chiny.

Sporo też uwagi poświęcała planom budowy Biblioteki Prezydenckiej Johna F. Kennedy'ego, którą oficjalnie otwarto w 1979 r. W uroczystości brał udział prezydent Jimmy Carter i liczne osobistości polityczne USA.

Jacqueline Kennedy Onassis podtrzymywała kontakty z rodziną Kennedych i z nielicznymi przy jaciółmi z przeszłości, starając się nie być w centrum uwagi opinii publicznej. I chyba to się jej udało, choć do końca budziła żywe zainteresowanie rodaków. Czasem pisano o niej i Maurice Tempelsmanie, towarzyszu jej życia w ostatnich latach.

W 1992 r. Jacqueline Kennedy Onassis zaangażowała się w poparcie dla Billa Clintona. W czerwcu 1992 spotkała się z Hillary Clinton, a ich krótka w zamierzeniu rozmowa przeciągnęła się w przyjacielską prawie czterogodzinną rozmowę. Jackie z pasją mówiła o książkach, które chciała wydawać. Podzieliła się także doświadczeniami o życiu w Białym Domu i wychowywaniu tam dzieci. „Była ona przekonana, że mój mąż wygra wybory i starała mi się udzielić porad", jak wspominała potem Hillary Clinton (s. 328).

Jacgueline Kennedy Onassis zapytana kiedyś, czy napisze pamiętniki, odpowiedziała, że nie i, że nigdy nie czuła takiej potrzeby. I dodała: „Nigdy 
nawet nie prowadziłam dziennika. Myślę, że chciałam po prostu swoje życie przeżyć, a nie je rejestrować. I wciąż jestem zadowolona, że tak uczyniłam" (s. 337).

Jacqueline Kennedy Onassis zmarła 19 maja 1994 roku w Nowym Jorku, a w uroczystościach pogrzebowych, choć miały charakter prywatny, brały udział tłumy Amerykanów. Amerykańska First Lady spoczęła na cmentarzu w Arlington obok pierwszego męża, prezydenta Johna F. Kennedy'ego. 